\title{
A figurational analysis of the role of the church in handling issues of widowhood amid Covid-19 in northern KwaZulu- Natal, South Africa
}

\author{
Zanele Gladness Buthelezi \\ Faculty of Arts \\ Department of African Languages and Culture \\ University of Zululand, South Africa \\ ORCiD- https://orcid.org/0000-0002-4330-8094 \\ Email-ButheleziZG@unizulu.ac.za \\ Thandiwe Nonkululeko Ngema \\ Faculty of Education \\ Department of Arts and Language Education \\ University of Zululand, South Africa \\ ORCiD- https://orcid.org/0000-0002-5915-5619 \\ Email-NgemaT@unizulu.ac.za
}

Doi: https://doi.org/10.46222/pharosjot.102.26

\begin{abstract}
This study sought to investigate the role of the church in handling issues of widowhood amid the rampant Covid-19 pandemic using Christian teachings and Ubuntu in selected parishes in KwaZulu-Natal (KZN), South Africa. Widowhood is a social phenomenon caused by a transition from married status to being a widow or widower due to the death of a spouse. Although a huge chunk of literature enumerates different ways in which widows have been ill-treated and treated as second citizens by communities over the years, this article argues that men grieve too and have also been affected by the Covid-19 pandemic. There is undoubtedly little state of balance between men and women in societies, but the reality is that men can also feel physical and emotional pain due to the loss of a spouse and they too need support in order to be able to move forward after experiencing a loss. They therefore cannot be divorced from being part of an intertwined church figuration where the concern is in 'process', not 'state' (Elias, 1978). This study is gender inclusive in that it focusses not only on women but also a range of experiences of widowers during the Covid-19 pandemic.
\end{abstract}

Using figurational sociology by Elias (1978), this qualitative study adopted an Interpretive Phenomenological Analysis (IPA) to interrogate the role of the church in the lives of the widowed during the pandemic. Selecting ten widowed congregants from different African churches in northern KZN as part of figurations, the study sought to explore what role the church has played to support the widowed when death occurred during the Covid-19 pandemic. By using figurational sociology, widowhood research problems are perceived in processual terms with shifting asymmetrical power balances. Data was collected through praxis essays and semi-structured interviews of 5 widows and 5 widowers, with all participants purposively selected. Findings reveal that the church has struggled to provide care and support because of regulations such as social distancing and government prescribed alert levels which restricted movement in society. Even 
though the widowed understood Covid-19 regulations, they have felt alienated and marginalised during their period of bereavement. The perceived lack of support ruptured loyalty and fractured interpersonal relationships during and after the time of mourning. The study recommends new ways of pastoral care and advocates for a figurational care model as an arsenal to support people, mending relationships and restoring dignity.

Keywords: Covid-19 pandemic; Widowhood; figurational/process sociology; the Church; figurational relationships; discrimination and marginalisation.

\section{Introduction}

Since the outbreak of the coronavirus disease (Covid-19) in 2019, people have died in large numbers worldwide. When a loved one dies, the bereaved person needs support from friends, relatives, colleagues, fellow congregants and other community members. Quite a number of people have become widowed due to illnesses associated with Covid-19. Although Oniye (2007) aligns widowhood with a woman who survives her husband and has not remarried, the context of this work uses both widow and widower so that men who survive their wives are also roped in. Losing a spouse is incredibly stressful. It non-consensually pushes an individual into a new status of being a widow or a widower. Widowhood as a process is characterised by pain which is aggravated by the traumatising fear of the widowhood effect, should the widowed person contract Covid-19 as well.

According to The Commission on Gender Equality (1997), widowhood needs to be viewed as both a social and intra-psychic phenomenon. A widowed person usually experiences loneliness, sickness due to stress and societal change in identity. Nwachukwu (2013), argues that the widowed find themselves in the middle of the ocean of life where they struggle to survive. Saluun et al. (2019) further assert that the stress of the phenomenon of widowhood is as real as that of loneliness and divorce. According to Sossou (2002), the death of a husband comes with extra significance because it represents not simply the departure of a partner, a friend and breadwinner, but also results in radical change in the woman's social status and life style, phenomena which also apply to men. Because of intense emotional stress, the bereaved are in dire need of expressing their feelings of loss before they can start to reorganize their lives (Saluun et al, 2019).

Due to lockdown restrictions and health protocols such as social distancing, visiting one another became problematic. This study sought to investigate what the role of the church has been during the Covid-19 pandemic and if practices of selected churches resonated with Christian teachings and Ubuntu even under globally trying times. The church is expected to intervene and assist the widowed during the painful emotional time and against alienation, discrimination and stigmatization, and other forms of neglect and maltreatment during bereavement. As time and timing are critical tools for co-ordination of social phenomena (Elias, 1978), the focus is on widowhood and church care immediately after the loss and a few months of the period of mourning after the outbreak of Covid-19.

\section{Literature Review}

This section reviews literature described by Meho and Tibbo (2003) as searches used primarily to unearth research views and concepts that have been done on a research topic or to find background information on a research problem. The scholars undertake these searches from publications and from people believed to be knowledgeable about their topic and can give advice 
or provide suggestions. Literature review discussed in this article covers international perspectives and African perspectives, and has been narrowed down to the views of the problem investigated in the study. The concept of widowhood, cruelties in the name of culture and traditions and, women's experiences of alienation and exclusion are also interrogated to an extent.

Although literature that is being reviewed puts emphasis on women because over the years they have been the most affected, it should be borne in mind that the analysis of widowers' lived experiences later in this article pose critical revelations viewed in church context.

\section{The outbreak of coronavirus disease (Covid-19)}

The coronavirus disease, abbreviated as Covid-19, is caused by a virus first identified in Wuhan, China in 2019. As this is a new virus which has not been previously identified in humans, scientists discover new information about it ever since. Although the exact source of the virus is not yet known, there is speculation that it might have originated from bats like other beta coronaviruses, MERS and SARS-CoV. It is a dangerous disease which can be mistaken for flu but can cause severe illness such as infection of the respiratory tract. Since December 2019, the Covid-19 pandemic has swept across the globe spreading death, sickness, trauma and hardship in its wake (Liu \& Modir, 2020; Horesh \& Brown, 2020).

South Africa responded to the outbreak of the disease by declaring a state of disaster in terms of the South African Disaster Management Act 57 of 2002. Measures to curb the spread of Covid19 were enforced through national lockdown which came into force on the $26^{\text {th }}$ March 2020. Measures introduced included promotion of healthy hygienic practices such as washing of hands, wearing of masks and social distancing; prohibition of large gatherings; limiting interprovincial travel; closing of national borders particularly for non-citizens; repatriation of citizens and their screening, testing and quarantining those who show symptoms; and promotion of self-isolation for those who have tested positive for Covid-19.

Under these circumstances, the disease continued to cause havoc in peoples' lives and institutions including the church. Horesh and Brown (2020) assert that rapid acceleration of transmission and lack of preparedness to fight the disease have had far-reaching negative impacts on all human life globally. Many have lost their loved ones and are still mourning; some have survived infections while others are still living in fear of getting infection as this enemy is omnipresent but is invisible. As the disease has caused tremendous stress on all aspects of society globally, this article seeks to understand the role of the church in the lives of those who lost their spouses. Some of the bereaved partners have been infected too, to such an extent that many did not bury their better halves because they were hospitalised and critically ill themselves. One cannot underestimate the aggravation of pain caused by losing a spouse and being in fear of dying too. As human solidarity has been constrained by lockdown regulations, people have been engulfed by uncertainty and the overwhelming sense of fear of the unknown. This research sought to investigate how African churches in rural areas of northern KwaZulu-Natal have coped with regards to the lives of those who were widowed by the advent of Covid-19.

\section{Widowhood and grieving stages necessitating intervention}

Saluun et al. (2019) enumerate stages of grief as follows: after the death of the spouse, first, the survivor reacts with shock and disbelief, second, the fact of loss sinks in, third, the sinking in of facts is immediately followed by inexplicable sadness; fourth, survivors relive the death 
and embark on a journey to search for meaning, and fifth, it is after 2 years that the survivor becomes socially active. Sekgobela et al. (2018) caution though that some survivors never recover from the ordeal and they find it very difficult to cope with the situation and even fail to adjust into new life pattern. Similar to Saluun et al. (2019), although put differently, Axelrod (2020) and Kübler-Ross (1969), enumerate five stages of grief and loss which are as follows: first is denial and isolation which is a defense mechanism to lessen pain, second, it is anger where the survivor may be angry against the deceased or the doctor who failed to prevent death, third is bargaining which is portrayed in feelings of vulnerability and helplessness where the survivor (s) utter the 'only if ...' statements, fourth is two pronged forms of depression, the first one being a reaction to the practical implication related to the loss and the second one is being subtle and private as the survivor is preparing to bury the loved one and, fifth, is acceptance which is marked by withdrawal and calmness. Axelrod (2020) refers to the latter stage as a gift that is not afforded to everyone.

Like Sekgobela (2018), Axelrod (2020), cautions that survivors do not necessarily go through the stages in the same order or experience all of them. It follows then that people's temperaments play a major role on how they react to grief. Axelrod (2020), classifies these reactions by saying some people, anywhere, may moan outwardly (wear their emotions on their sleeve) while some experience their grief internally and may not even cry. Correspondingly, deducing from the study he conducted among 358 widows, Kathomi (2019), affirms that many widows experience grief in a non-linear progression. Subsequently, emotional support is somehow neglected since some widows may be neglected when it is assumed that their grieving is over. Amazingly, though, research has discovered that despite the intense grief widows undergo, they are also subjected to the excruciating agony as their spousal families perform cultural rituals to them. Some of these rituals are very cruel.

\section{Oppressive practices in the name of culture and traditions}

Nyangweso (2017), posits that indigenous cultures and religions are a harbinger of identity and a people's heritage. This is supported by Khosa-Nkatini et al. (2020) who assert that some African cultures and their durations have good practices which benefit Africans in many ways. Practices which show Ubuntu include staying longer with the family after burial and regular visits by relatives and friends as a form of support. Furthermore, neighbours sometimes offer help by providing food and taking care of children for the bereaved family. This is appreciated by many even though there are African cultures which do not uphold values of widows as human beings. Widows should enjoy the human rights as enshrined in the constitution (Modise, 2016; Baloyi, 2016 and Kapuma, 2018) and not be exposed to cultures which are painful. Painful experiences are considered as acts of deprivation, subjugation and humiliation to the already suffering soul (Salluun et al., 2019; Idialu, 2012; Ajiboye, 2016 and Kapuma, 2018). The assertion is further clarified by Saluun et al., (2019), who states that each culture determines the rationality of practices relating to widowhood and mourning rites. It is then upon different communities to moderate and concentrate on what upholds human dignity for both widows and widowers.

It is true that, in terms of rituals, widowhood affects more women than men (Gbenga, 2010). For instance, in countries like Malawi, Zambia, Kenya, Tanzania, Malawi, Zimbabwe, Eswatini and South Africa, while widowers receive much support from their families and community in general, widows are forced to undertake dehumanising activities. For example, while widowers only require the slaughtering of goats and cows for cleansing that in fact prepare them to get married after their wives' death, widows are subjected into having sexual intercourse with strangers or members of the family especially, brothers of the deceased, as part of their cleansing (Nyangweso, 2017; Baloyi, 2017; 
Kapuma, 2018). They are further, even handed over to the so called professional village cleansers for sexual cleansing. These cleansing rituals clearly indicate that widowhood in women is associated with impurity that requires sexual activities for cleansing (Ajiboye, 2016; Baloyi, 2016; Baloyi, 2017 and Nnodim et al., 2013). Subsequently, Baloyi (2016) condemns the act of sexual cleansing as being dehumanising and a means to subject widows to subordination and oppression. Moreover, several researchers aver that the women are exposed to unprotected sex which subsequently increase chances of HIV infection and many infectious diseases pass on to women who may die and leave their children being orphans (Curnow \& Watts ,2013; Baloyi, 2016; Nyangweso, 2017; Saluun et al, 2019 and Kapuma 2018). Baloyi (2015) condemns and further attributes the act to a patriarchal mindset that uses sex as a means of domination among the Africans.

Moreover, in many African countries such as Zimbabwe and Tanzania, while widowers continue to enjoy life as before the bereavement, women are seen as a symbol of bad luck and have to take back-seats in cars, buses and even in family affairs (Ajiboye, 2016; Baloyi, 2015; Baloyi, 2016; Kapuma, 2018). The assertion is supported by Manala (2015), who reveal that widowed women are even forced to wear black clothes. However, Hancox (2013) in the study that was conducted in South Africa, discovered that widows wear mourning clothes of different colours depending on their customs, family traditions and churches. Additionally, several authors posit that these widows, for a period of time, have to stay indoors, shave their hair, are forbidden to bathe, are not allowed to plait hair, need to sleep on the floor, are advised never to sleep during the day and are made to swear at the husband's corpse (Nyangweso, 2017; Baloyi, 2016; Makgahlela \& Sodi,2016; Modise 2016 and Kapuma 2018). In some cases, widows are locked in with their husband's corpse for several hours and expected the drink water that had been used to wash the husband's corpse.

This section concludes by concurring with Baloyi (2017), Nyangweso (2017) and Saluun (2019) in describing death as a painfully tragic event that challenges the emotional and spiritual understanding of every individual, including men. It is against this backdrop and the outbreak of Covid-19 that this research investigated the role that the church plays in issues of widowhood using Elias's process sociology as a lens of analysis.

\section{Research Methodology}

\section{The research design}

Chilisa and Preece (2005: 142) describe qualitative study as 'a type of research inquiry in which the researcher carries out research about people's experiences, in natural settings, using a variety of techniques such as interviews and observations, and reports findings mainly in words rather than statistics'. The study focuses on analysing lived experiences of the widowed amid Covid-19, and the identification of support systems in churches used to help them cope with grief and fear.

The study adopted the interpretive paradigm, which was chosen because of its ability to allow the researcher to 'get inside the person and understand from within' (Cohen, Manion \& Morrison, 2007: 22). Based on this statement, the narrative enquiry allowed the widowed space to narrate their lived experiences. This is in line with what Chowdhury (2014: 433) sees as the importance of interpretivism because of its ability to enable the researcher to see the world through the eyes of the people who are being studied and to allow them multiple perspectives of reality. 


\section{Population and sampling procedures}

Sampling refers to the selection of a subset of persons from a larger population, also known as a sampling frame (Scott \& Morrison, 2007:219), with the intention of representing a particular population (Neumann, 2011:246). Five widows, five widowers and five church leaders, all from Zulu speaking communities, were purposively sampled from selected churches in rural northern KwaZulu-Natal. Etikan et al. (2016) define the purposive sampling technique as a deliberate choice of a participant due to the qualities the participant possesses. Participants chosen for this study have lived experience of widowhood and all belong to specific parishes situated in the Zululand, UMkhanyakude and King Cetshwayo Districts in KwaZulu-Natal province, South Africa.

The sampling procedure described above was in line with Bhengu's (2005: 58) recommendation that a researcher may need to choose participants who are information-rich if they are to make possible an in-depth analysis of the phenomenon being studied. This way of thinking confirms one of the criteria for selecting participants purposively, as discussed by Stones (1998), who argues that it is of the utmost importance that the participants have experienced the phenomenon under investigation.

\section{Data collecting methods}

Collecting data was not an easy thing to do under Covid-19 circumstances because regulations to curb the spread of the virus and limit the rate at which new infections increase were still in force. Data was collected using semi-structured interviews. Some of the engagements with participants were face-to-face, while other encounters were done virtually. Interviews gave participants an opportunity to attach meaning to their lived experiences (Mertens, 2014). This method of gathering information through orally using a set of pre-planned core questions was accepted by the participants. According to Shneiderman and Plaisant (2005), interviews can be very productive since the interviewer can pursue specific issues of concern which often help to yield focussed and constructive data.

Semi-structured interviews were very useful in providing consistency in questioning all the widowed participants and church leaders. The researchers prepared a set of pre-planned core questions for guidance such that the same areas were covered with each widow and widower. Church leaders had a different set of questions relating to what they believe they did or did not do and what they think they can do further to provide support to the widowed and the duration of such lending a hand. All interviews lasted up to an hour and follow- up interviews were conducted telephonically. For sensitive questions which appeared to bring up excessive negative emotions, participants were allowed to write praxis essays. Evidently, these literary compositions were used as a further tool for data collection so that the widowed were afforded an opportunity to express their thoughts and emotions and explain how they went through the journey of widowhood under the trying Covid-19 times.

\section{Data analysis}

According to Benard (1994: 360), data analysis refers to 'searching for patterns and ideas that help to explain the existence of those patterns'. Chilisa and Preece (2005: 56) point out that "the purpose of analysing and synthesizing data is to make sense out of disaggregated information, showing relationships, their root causes and possible solutions".

This study used Interpretative Phenomenological Analysis (IPA) to make sense of data. This is an inductive approach (it is 'bottom up' rather than 'top down') which 'does not test hypotheses, 
and prior assumptions are avoided' (Reid, Flowers \& Larkin, 2005: 20). It is an approach which helps to interrogate and analyse insights into how a given participant, in a particular context, makes meaning out of their lived experience. It allows researchers "...to explore lived personal experience and 'is concerned with an individual's personal perception or account of an object or event" (Smith \& Osborn, 2007: 53). It was used in this study to hear the voices of the widowed who participated in the study. Thematic analysis as proposed by Creswell (2014) was adopted in this study. Content from IPA semi-structured interviews and praxis essays was coded in order to identify recurrent or underlying themes that existed within and across the solicited data.

\section{Theoretical underpinnings of the study}

Ocholla and Le Roux (2011: 1) define theoretical framework as 'the structure that holds and supports the theory of a research work. It serves as the lens that the researcher uses to examine a particular aspect of his or her subject field'. Additionally, Grant and Osanloo (2014), regard it as a guide for the researcher in order to amplify and support a study. Similarly, Ravitch and Carl (2016) argue that the theoretical frameworks assist researchers in situating and contextualizing formal theories into their studies as a guide. The given definitions illuminate that any theoretical framework used becomes a lens for analysis and is part of a thread between the research problem, research design, data collection and interpretation of the findings.

As a lens for analysis and interpretation, this study chose figurational sociology of Norbert Elias, a Jewish German sociologist, born in Breslau (now Wroclaw in Poland) in 1897. As a member of a despised Jewish community within Germany, Elias experienced conflict, prejudice and discrimination, flowing from out-group pressures, or what he termed 'established-outsider relations' (1978) and an 'identity crisis'.

Figurational sociology of Norbert Elias has become a well-established theoretical framework (Haycock \& Smith, 2010) over the past four decades. The theory has been used in educational research such as Inclusion and National Curriculum for Physical Education (Haycock \& Smith, 2010), PE teachers and Figurations (Green, 2002) in the UK, A Figurational Analysis of the Lives and Careers of Some South African Teachers (Wedekind, 2010) and Lived experiences of TVET lecturers' professional lives in the midst of change (Buthelezi, 2016). It has also been used in non-educational contexts such as Diffusion of Medical Innovations (Bessant, 2008), Health Professionals and identity (Korika \& Molloy, 2010) and Feminism and Figurations (Mansfield, 2008)). But the theory has not been used in researching experiences of the widowed women and men in a church context in South Africa.

The first key concept used in this study is that of 'figurations'. Elias argues that human beings live together forming complex networks of social relationships that he called figurations. These, he believed, link people, groups and institutions together. Elias believed that human beings are inescapably embedded in the social world around them and in this study that context includes the church. He refuted the closed self-image he called 'homo clausus'. The crux of homo clausus is the perception of man as a single isolated adult mind. His argument is therefore that a 'homo clausus' is a myth, as no person can be a 'closed man' or a 'closed-personality'.

In this argument, Elias was questioning the concept of the isolated ego, as he believed that all human beings are part of the 'we-images' or 'we-less l's' (1987a:266), because we are all interconnected to one another. Elias's conceptual standpoint is that of 'homines apert' or 'open people', who are bound together in intertwined relationships in various ways and degrees. Each 
of us depends on other people, particularly in times of sadness and loneliness; each of us needs a shoulder to cry on or to stand on the shoulders of others in times of need.

Elias's theory was chosen because of its emphasis on the interconnectedness of people through their intertwined actions and relationships that they are embedded in. Elias emphasizes intersubjectivity and promotes the notion 'of people in the plural' (Elias, 1978:121) which, I think, resonates with findings of this study as shall be discussed later.

\section{Discussion of findings}

This study investigated the role of the church with regards to the issues of widowhood in northern KwaZulu-Natal, South Africa. This section discusses findings, particularly caring for the widowed or lack thereof, and interrogates how the status quo can be improved in African churches.

Literature has revealed how over the years, widows have been exposed to inhumane rituals and harsh treatment after they lose their spouses. Examples include work by researchers such as Khosa-Nkatini et al. (2020) that widows are withdrawn from participating in the church until their mourning period is over. Moreover, some widows were forced to stay at home for fear of defiling the church house. This study further confirms that churches prove to have imbibed the traditional spirit of ostracizing widows instead of embracing them (Manala, 2015). It is heartbreaking for the widowed to be viewed as a defilement and a symbol of bad luck in communities which in many ways consider themselves as being 'civilized' while their male counterparts enjoy the social status that they enjoyed prior to bereavement.

In addition to the plight of women summarised above, this study was gender sensitive in that male participants were not excluded. This was a conscious decision because loss of a wife also "chains them' to widowhood. It was perceived as a research gap that not many studies rope them in due to a justified perception that the majority of women are the most affected because of exposure to patriarchy. But the pain of losing a spouse knows no gender and men, in this study, are seen as being part of the intertwined chains of relationships in complex church figurations. A man is also a social being within a church milieu, a 'human being among other human beings' (Elias, 1978: 13), in different configurations that are part of this social structure. Within this setting men play a variety of roles and are also affected by social interactions with different people at all levels of church life.

Many researchers are agreeable that since Christianity has its roots in the Holy Bible, it has to uphold peoples' well-being. The Bible demonstrates that safeguarding basic human rights is the central practice. There are many chapters with verses that encourage upholding human rights such as the right to equal treatment, freedom of thought and expression, fair treatment before the law, freedom of conscience and protection from torture and slavery. In both the Old and the New Testament, caring for the widows, strangers and orphans is highly emphasised. God's compassion for widows became the covenant community's responsibility which the early church naturally took up (Acts 6, 1; James 1, 27). One would expect that the church adopts models used in the Bible (Ndlovu, 2013; Modise, 2016; Phillip et al., 2015; Kapumi, 2018) to mitigate widowhood problems.

Where widowhood and the role of the church is concerned, the starting point should be to examine how the widowed are seen through the eyes of the Holy Bible. The following scriptures clearly illustrate that God is fond of and willing to defend the widows, the orphans and the poor: Exodus chapters 6; 21; 22, 23, and 24. Deuteronomy 10; 17; 18; 19; 24 and 27. 
According to Isaiah chapters 1 and 17, the manner in which the nation treated widows measured how it practiced Godly justice among people. Job, in the book of Job chapters 1-4; 14 and 21, though in agony, described an evil man as one who does not take care but instead oppresses the widow, orphan and the poor. Likewise, prominent prophets like Jeremiah and Isaiah criticized the ill-treatment of widows (Jeremiah chapters 7, 4-14; Isaiah chapters 1, 2, 10 and 23). Additionally, Isaiah 54 verses $1-4$, offer profound comfort to widows and to the childless women (Nyangweso, 2017, Philip et al., 2015 and Baloyi, 2017).

\section{Constrained care and support for the widowed by the church}

Under Covid-19 circumstances, this study reveals that solidarity from the church was negatively affected by the outbreak of the Coronavirus disease and subsequent lockdown regulations and restrictions. Everyone was overwhelmed by fear and going to other peoples' houses was strictly prohibited. This eventually led to some level of unintended neglect and inadequate care and support for the widowed. Two of the participants said:

Female participant 3: Loneliness was unbearable. These are times when one needs support the most. Death under Covid-19 is one such time. Not many people came, understandably so. Even the senior pastor did not come, only junior evangelists came to my house. I felt neglected and unimportant.

Female participant 1: Losing my partner was painful. This was worsened by the fact that he had died of Covid-19. I felt traumatized and helpless. Although people came to express their condolences, nobody prepares you for the journey ahead. Days were darker because I was also not feeling well. Self-isolation when I was bereaved left my children traumatized.

What transpires from the extract is that widowhood is a painful journey in which the affected need support, not only during preparation for a funeral but also after burial and the earlier part of the mourning period. The journey is arduous even in the absence of Covid-19. The outbreak of coronavirus disease complicated the situation even further. The bereaved felt lonely, helpless and neglected as very few fellow congregants could come to offer their condolences. Pain of losing a loved one, fear that the person may also die of the disease or widowhood effect was rife. Lived experience of loneliness was also affirmed by a widower:

\section{Male participant 3}

It is unbearable pain and loneliness that I felt. Not much support came from the church after the funeral. People assume that one is okay after this sad day but this is not the case at all.

However, the participant below shows that not all was doom and gloom. Some of the churches, although very few, were exemplary on how they used available technology to ensure that the widowed were afforded emotional support. Small groups were sent in person while others comforted the widowed through video calls, telephone conversations, emails and texts. But it should be noted that very few in rural communities have these resources as the majority of the people in the KwaZulu-Natal province are poor due to high unemployment rates which permeate the entire country.

Female Participant 2: Losing my husband was a terrible thing. But then, belonging to a small intimate congregation helped me. My husband's family never worried me, instead, I got all the support. I got overwhelming support from 
church ladies through calls and messages. Personally, I was never lonely. Through telephone conversations I got a chance to share how I felt.

Clearly, this participant belonged to a middle class income-group. She could afford a cell phone, data and airtime. The majority of people in rural communities go to sleep hungry due to dire poverty which engulfs them. This situation was worsened during Covid-19 because even those who had jobs were retrenched when the economy of the country took a nose-drive. Covid-19 exposed inequalities globally as well as those which exist in our African communities. One of the pastors attested to this when he said that churches with poor low class congregants could not have helped anyone because they collapsed. Only churches with better resources could continue to support the widowed because their congregants are well to do and were able to pull through even under the terrible time of the Covid-19 pandemic.

\section{Expectation to give more money to the church}

There are assertions from participants that church leaders saw congregants, including the widowed as a possible source of income. Even though not much support from the church was forthcoming due to fear of coming together in the midst of the pandemic, church leaders pressurised people for hefty tithes after insurance pay outs. Instead of being given adequate emotional support, some of the grieving congregants were seen as a source of riches for the church because of their inheritance:

Female participant 4: Although I cherished my church and I was always helping by offering a lot of help to others before the painful days and Covid19 , the church did not return the favour by offering support. Instead, I was called by my pastor who jokingly reminded me not to forget to tithe when my husband's monies are released.

Another participant confirmed the assertion:

Female participant 1: As our business had already collapsed because of lockdown, I was at the verge of bankruptcy. Timing of my husband's departure was so off. Very few fellow congregants supported me. Instead of comforting me, the church elders kept on sending messages to remind me of the financial contributions that are expected. They surely were not aware that I lost everything. I am starting from scratch.

From what participants are saying, it is clear that fellow congregants became insensitive and this was not what the widowed had anticipated. The church would be expected to be aware when a member is struggling financially so that there are interventions of support and care. One becomes a congregant because of being part of a church figuration. Each one is connected to others and all are 'mutually oriented and dependent people' (Elias,1978:261). The need for interdependence comes more to the fore in difficult times like losing a spouse particularly amid Covid-19 and similar draining experiences. The widowed would benefit from a stronger, fruitful, sensitive and intertwined relationship within a complex social context, the church.

Sanctified materialism, where money seems more important than lives and wellbeing of congregants, is prevalent in some of the present-day church settings. This situation was aggravated during Covid-19. Subversive worldly elements such as mammon or greed and excessive love of money creeps into the church, a phenomenon antithetical to church teachings 
irrespective of denomination. Materialism is considered by the Bible as one of the most dangerous sins which congregants have to fight at all cost.

\title{
Pressure to get married soon
}

Further responses from praxis essays indicate that male participants were the most vulnerable and comparatively needed more support than women. African culture does not expose men to chores like cleaning the house, taking care of children and cooking. This has always been seen as a key role for women in rural black communities. This research shows that men losing their female spouse become more helpless and this situation escalated in the midst of Covid-19 because not many congregants and relatives came to support the bereaved. There was also pressure from elders to remarry a few weeks after the funeral. One pastor who lost his wife due to a Covid-19 related illness said:

\begin{abstract}
Male participant 5:
As a pastor, the church gave me adequate support as far as prayer meetings and funeral preparations were concerned. But then pressure to get married again got too much a few weeks after the funeral. It was too soon for me. Some of the women started parading themselves, their daughters or their relatives during some of the visits. But, honestly, I had no taste, my eyes did not appreciate anything and could not love anyone.
\end{abstract}

The fact that a pastor received adequate support shows that power ratios are uneven and that interdependence does not mean that people are equally interdependent (Elias, 1978). The level of support received was of a better level if compared to others' because he is a leader. Such inequality and hierarchy Elias (ibid) describes as social processes which humiliate people as individuals or as groups. His story is also different in that instead of being rejected, congregants saw him as an 'asset', 'a potential husband', if he decides to remarry. This display of lecherous behaviour from congregants was embarrassing for him as all he expected was ordinary support. The same sentiment was shared by another respondent thus:

\begin{abstract}
Male participant 2: The only type of support I got from church members was being shown which woman I can marry next. Crazy solution because it is not easy to just replace a spouse, bereavement is a draining experience. I became withdrawn and Covid-19 restrictions helped me in a way. Virtually, you find no reason to live. It becomes a shocking realization that your wife was a pillar and a think tank in the home.
\end{abstract}

The emotionally devastating experience and intensified pain led to the psychosocial response of being withdrawn. This shows that congregants are not isolated monads without feelings (Buthelezi, 2016), they are homines aperti (Elias, 1978), reflecting and feeling beings who are bound to be affected by other peoples' actions. When death strikes, particularly under a pandemic like Covid-19, the church must not only evangelise (Baloyi, 2017) and conduct burials but should also stand firmly by the side of the widowed because it can be a lonely arduous journey.

\section{Discrimination and marginalisation}

Weaknesses in a web of relationships within the church is evidenced as having led to resentment and dissatisfaction which Elias (1994a) views as triggering either subservience to authority by following prescribed etiquette or aggression whilst within the system, or fleeing from oppressing to more enabling parishes. One respondent explained thus: 


\begin{abstract}
Female participant 1: I was treated as a stranger. Other women were afraid that I would steal their husbands. I suddenly became voiceless and felt nonexistent. And as soon as Covid-19 restrictions were loosened, I went back to the church I attended before I got married. Given a chance, I would advise churches to revisit the way the widowed are treated.
\end{abstract}

There was frequent reference to more and more widowed persons who decided to quit church during Covid-19 to rather stay at home or move to another congregation for hope of better treatment. These resultant negative decisions to quit were as a result of 'indefinite rationally undefined fears and anxieties' (Elias, 1939:116; Elias, 2000) which eventually destroy attributes such as enthusiasm, commitment and loyalty to the church.

Moreover, widows expressed exposure to the pain of marginalization as one participant said the following:

Female participant 3: If I could turn back the hands of time, I would. I feel so tearful that as a minister's wife, I did not take care of the widowed in my church and community. My husband's death has been an eye opener to me. As an ordained minister, I co-pastored the church with my husband. When he died, the funeral service was satisfactorily attended, church members and other ministers' wives supported me and I felt comforted. But after the funeral not many people cared to even phone me. Two female elders approached me after church and advised me not to come to church for three months. Within two weeks my husband was replaced by a much younger pastor whose wife was cold towards me. Church members entertained the new couple and forgot completely about me. Apart from trauma of losing a husband, I felt marginalized and discriminated against. Besides help from other widows, I was as good as on my own.

Although the above assertion was not caused through the existence of Covid-19, it only reveals prevalence of alienation, mockery to widows, insecurity and stigmatization, discrimination and marginalisation, and insensitive lack of church care and support with shifting asymmetrical power balances.

Overall, this study argues that the church can't afford to be complacent about issues of widowhood and calls for the church to stand firm even against Covid-19 adversity and help during bereavement until the widowed are able to pick themselves up again. It is the view of this article that the caring advocated for the widows be extended to the widowers too.

\title{
Widowhood and new identity amid Covid-19
}

In life, it is not possible for anyone to escape loss, and Covid-19 makes this more of a reality as people die at an alarming rate. This study focussed on loss of a spouse which has been seen to be evoking terrible emotions of pain and vulnerability. This section discusses new identity created through widowhood and Covid-19 from the day the husband or wife passes away.

Firstly, one gets to be called a widow or widower, a status accompanied by unacceptable stigma and discrimination. Conceptualisation of stigma can also be associated with the church as a social context. Goffman (1963) describes what he calls 'spoiled identity' and how this affects the stigmatized individual and their social life (Goffman 1963). He describes stigma as referring to "an 
unfavourable attribute that is discrediting" (Goffman, 1963: 13). This research has uncovered theses in the church social relationships where widowed individuals are stigmatized by people considered to be 'normal' (Goffman, 1963). This study reveals that widowhood identity affects the widowed negatively and critical analysis of praxis essays exposes that change of identity due to loss affects the way they see themselves and perceive their social identity.

Furthermore, this research reveals that widowhood brings with it 'depersonalizing and isolating tendencies of modernity' (Elias; 1985a:181) which include discrimination, stigma and being seen as 'defective'. From data solicited, some of the participants voiced their feelings thus:

Male participant 5: There is new identity attached to you as a person. You are referred to as 'the one who lost his wife through Covid-19'. It does sound like one is disabled somehow. It comes with a new name and stigma that stays with you forever.

Feelings of regret about the past, rejection by fellow congregants seemed to have aggravated the traumatic experiences which the widowed underwent. Appreciated is help from other widowed people who share the sentiment and displayed Ubuntu towards one another. Over and above Ubuntu, Elias (1978: 175) argues that people need each other, are directed towards and bonded to each other as a result of the division of labour, of occupational specialization, of integration into tribes or states, of a common sense identity, and their shared antagonism for others or their hatred and enmity towards each other. The deceased minister's wife and other widows share the widowhood identity and are part of this figuration through loss. Through widowhood they are exposed to 'stigmatization as the outsider group' (Elias, 1956: 17), alienation which the church needs to rid itself of by showing support in various ways even amid the pandemic.

Furthermore, the fact that one female participant was told not to come to church anymore depicts that interdependence is inextricably bound to issues of power. Power forms an integral element of relationships and in the above example is reflected as being distributed unevenly in the church figuration.

As has been explained above, Elias (1978) asserts that it is possible that people bond to each other due to a common sense of identity and shared antagonism for others (1978:175). The ingroups which the widowed join is expressed by the respondent thus:

Female participant 3: They invited me together with other widows and widowers to dinner, they invited us to go for walks.

Figurational sociology views the sense of belonging to a group as an inescapable social occurrence. The widowed used get-togethers as one of the coping strategies because of gruesome lived experiences. Elias (1978) coined the terms 'group charisma' and 'group disgrace', to refer to ambivalent relationships between established we-image and outsider social groups, respectively. This encourages divisions in the church and could be minimised by devising strategies to fight stigma, isolation and discrimination.

Further insensitive utterances and lack of collegiality towards the widowed were detected from other responses and praxis essays:

Female participant 5: They mocked me saying the 'high heel lady is on flops now'. When I came back to church, having tried to pick myself up from the horrible rituals, fellow congregants said 'abangishukanga kahle' which means 
'I was not punished enough'. This meant that my suffering was their joy.

Female participant 1: When churches opened after a complete Covid-19 shutdown, I started going back to sermons again. There was a lot of gossiping behind my back. When I dress smart, they accused me of aiming to snatch their husbands. I feel lonely, marginalized and suspected to prostitute...

Being called names and suspected of mischief by fellow congregants is humiliating. Smith (2001:157) describes such humiliation as 'painful feelings of displacement and severance', where victims 'feel cut out from their established niches and ejected from their old haunts'. Elias (1978) argued that feelings of humiliation make people to feel despised, inadequate and pushed down by others or by authority as has been the case with the widowed in this research.

To conclude this section, we argue that identity is not cast in stone as it shifts over time (Sharp, 2014). This is supported by Elias (1970a: 128) who elucidates that although 'one's sense of personal identity is closely connected with the 'we' and 'they' relationships of one's group, and with one's position within those units of which one speaks as 'we' and 'they', the figurations to which they currently refer can change in the course of lifetime, just as any person does himself or herself'. Therefore, change in identity, stigmatisation, isolation, discrimination and vulnerability can be used as stepping stones to growth after being widowed.

\section{Conclusion}

This article has used the concept of 'figuration' to discuss interdependence which show that any person cannot exist in isolation, but is connected to other people even under the unprecedented Covid-19 pandemonium. By figurations, Norbert Elias was referring to interweaving and interdependence of actions in human relationships, which also exists in church context. A widowed person as an individual and the church as 'society' should not be seen as static isolated entities, but as being intertwined, particularly in times of grief.

Findings in this research revealed that people are affected by unfortunate, unprecedented incidents such as the Covid-19 pandemic. Human beings are not perfect and become weak and distraught when death occurs. This research has shown that the widowed needed physical, emotional and psychological support from fellow congregants due to the excruciating pain and intense grief caused by loss of a spouse. Support from the church has been found to be minimal during a time when the widowed find themselves between the rock and a hard place due to Covid19. Stigmatization, discrimination and alienation of the widowed are prevalent in churches. They find themselves being exposed to negotiating the newly acquired identity of widowhood. They become part of a new insider group of stigmatized individuals, who may isolate themselves spatially from 'normal' people (Goffman, 1963: 35).

Allowing fear to take over led to neglect which is grossly against Ubuntu philosophy. This research sounds a clarion call on the need to support the widowed by the church. Hospitality towards the widowed is central to the African sense of morality. Church exists as a revolutionary movement that promotes human worth and dignity (Nyangweso, 2017) and it should aim to mediate against incidences of human neglect, particularly during bereavement under Covid-19.

The church needs to demonstrate the power of God by providing emotional support through phone calls and material needs even against Covid-19 adversity. As part of the body of Christ, the church has been taught to 'fear not' and cannot stand by and watch the processes of powerlessness unfold and do nothing about them. Enshrined in church teachings is to trust the 
Lord and congregants need to regroup and find new ways of fighting the enemy disguised as Covid-19. Elias (1978:175) proposes a non-individualistic approach to solving problems of widowhood even amid the Covid-19 pandemic. He asserts that 'people need each other, are directed towards and bonded to each other ...' because of a common sense of identity of belonging to a church.

There is a lot that needs to be re-imagined about how the church takes care of its people, particularly during a pandemic like Covid-19. Novel methods for participation and supporting one another need to be developed and be used. While Kathomi (2019) advocates for the adoption of the pastoral care model where the rights of the widows are encouraged to ensure that their dignity is restored, this study proposes a figurational care model which includes men and all congregants as part of the intertwined connection. This stance fulfils process sociology's idea of people in the plural even within a church as a social figuration.

\section{References}

Ajiboye. T. (2016). What It's Like to Be a Widow in Africa. Gender \& Behaviour, 9(2), 4052-4072.

Axelrod, J. (2020). The 5 Stages of Grief \& Loss. Psychology Central. Retrieved on July 23, 2020, from https://psychcentral.com/lib/the-5-stages-of-loss-and-grief/

Baloyi, E. M. (2016). Theological Reflections on Sex as a Cleansing Ritual for African Widows. Alternation, 23 (2), 201-216.

Bhengu, T.T. (2005). 'Principals as Professional Leaders: Implications for Management of Rural Secondary Schools during Transition.' Unpublished PhD thesis, School of Educational Studies in the Faculty of Humanities, University of KwaZulu-Natal, January 2005.

Benard, H.R. (1994). Research Methods in Anthropology: Qualitative and Quantitative Approaches (2 ed) Thousand Oaks, CA: Sage Publications.

Bessant, J. (2008). The Sociology of policy making in the modern state: intent and human action. Journal of Sociology. 44, 283. Australia: Sage.

Best, J. \& Khan, J. (1989). Research in Education. Englewood Cliffs (NJ), Prentice Hall.

Buthelezi, Z.G. (2016). At the Policy-practice Interface: Exploring Technical Vocational Education and Training (TVET) Lecturers' Post-Apartheid Educational Reform Experiences. Unpublished $\mathrm{PhD}$ thesis, University of KwaZulu-Natal, Pietermaritzburg.

Chilisa, B. \& Preece, J. (2005). Research Methods for Adult Educators in Africa. Johannesburg: Pearson Education.

Chowdhury, M.F. (2014). Coding, Sorting and Sifting of Qualitative Data Analysis: Debates and Discussion, Quality \& Quantity, 49(3), 1135-1143.

Cohen, L., Manion, L. \& Morrison, K. (2007). Research Methods in Education (6 ed). London: Routledge Falmer. 
Commission on Gender Equality. (1997). Annual Report of the Commission on Gender Equality, Braamfontein: CGE.

Curnow, R. \& Watts J. (2013). Lawyer Fights 'Widow Sex' Tradition in Malawi. CNN News blog posted on 21 March 2013. Available at: www.editiuon.cnn.com

Elias, N. (1956). Problems of Involvement and Detachment. British Journal of Sociology, 7(3), 226-252.

Elias, N. (1970a). Introduction to African Art from the Collection of Norbert Elias. Exhibition Catalogue. Leicester: City of Leicester Art Gallery, reprinted as 'African art'." "Essays III: On Sociology and the Humanities." UCD Press 2009 (Collected Works, 16, 201-8 Dublin.

Elias, N. (1978). What is Sociology? (Originally published in German in 1970) London: Hutchinson.

Elias, N. (1985). The Loneliness of the Dying. (Originally published in German 1982) Oxford: Basil Blackwell.

Elias, N. (1987a). The Changing Balance of Power between the Sexes. Theory, Culture \& Society, 4(2-3), 287-316.

Elias, N. (1994a). Reflections on a Life. (Originally published in Dutch in 1987; Translated from the 1990 German edition) Cambridge: Polity Press.

Elias, N. (1996). The Germans: Power Struggles and the Development of Habitus in the Nineteenth and Twentieth Centuries. (Originally published in German in 1989), Cambridge: Polity Press.

Elias, N. (1998a). The Norbert Elias Reader. Edited by J Goudsblom and S Mennell, Oxford: Blackwell.

Elias, N. (1998b). Norbert Elias: On Civilisation, Power, and Knowledge. (Edited by S. Mennell and J. Goudsblom) Chicago: University of Chicago Press.

Elias, N. (2000). The Civilising Process: Sociogenetic and Psychogenetic Investigations. (Originally published in German in 1939; Original English translation 1978/1982; This edition 1994; Revised) Oxford: Blackwell.

Etikan, I., Musa, S.A. \& Alkassim, R.S. (2016). Comparison of Convenience Sampling and Purposive Sampling. American Journal of Theoretical and Applied Statistics. 5(1),1-4. doi: 0.11648/j.ajtas.20160501.11.

Gbenga E. A. (2011). Widowhood Practices and the Rights of Women: The Case of SouthWestern Nigeria 2011. Print.

Goffman, E. (1963). Stigma: notes on the management of spoiled identity. Englewood Cliffs, N.J.: Prentice-Hall. 
Grant, C. \& Osanloo, A. (2014). Understanding, Selecting, and Integrating a Theoretical Framework in Dissertation Research: Creating the Blueprint for Your 'House'. Administrative Issues Journal: Connecting Education, Practice, and Research, 4(2),12-26.

Green, K. (2002). Physical Education Teachers in their Figurations: A Sociological Analysis of Everyday 'Philosophies', Sport and Society, 7(1), 65 - 83. United Kingdom: Routledge.

Hancox, D. \& Feldman, K. (2013). Integral mission and shalom: Shalom for widows - an exploratory study from South Africa. $6^{\text {th }}$ Global Consultation, Lima: Peru.

Haycock, D. \& Smith, A. (2010). Inclusive physical education? A study of the management of national curriculum physical education and unplanned outcomes in England. British Journal of Sociology, 31(3), $299-305$.

Horesh, D. \& Brown, A. D. (2020). Traumatic stress in the age of COVID-19: A call to close critical gaps and adapt to new realities. Psychological Trauma: Theory, Research, Practice, and Policy, 12(4), 331-335. http://dx.doi.org/10.1037/tra0000592

Idialu, E. E. (2012). The Inhuman Treatment of Widows in African Communities. Journal of Instructional Psychology, 35(2).

Kapuma, G. A. (2018). Widowhood within the Malawian Context: A pastoral care model. Thesis (PhD), University of Pretoria: South Africa.

Kathomi, M. K. (2019). Assessment of an Effective Pastoral Care Model for Helping Widows Overcome Grief in Ack Kirinyga Diocese, Kenya. Journal of Arts and Humanities, 08 (04), 30-43.

Khosa-Nkatini, H.P., Wepener, C.J. \& Meyer, E.E., (2020). Tsonga widow's mourning rituals practices in the Evangelical Presbyterian Church in South Africa: A ritual-liturgical exploration, Theologia Viatorum, 44(1).

Korika, M. and Molley, E. (2010). Making sense of professional identities: Stories of medical professionals and new technologies. Human Relations 2010, 63. United Kingdom: Sage.

Kubler-Ross, E. (1986). Death: The Final Stage of Growth. New York: A Touchstone Book.

Liu, S. R. \& Modir, S. (2020). The outbreak that was always here: Racial trauma in the context of COVID-19 and implications for mental health providers. Psychological Trauma: Theory, Research, Practice, and Policy, 12(5), 439-442. http://dx.doi.org/10.1037/tra0000784

Makgahlela, M.W. \& Sodi, T. (2016). 'Cultural conceptions of a bereavement-related illness in a South African indigenous community', Journal of Psychology in Africa, 26(6), 541-545.

Manala, M. J. (2015). African traditional widowhood rites and their benefits and/or detrimental effects on widows in a context of African Christianity. Hervormde Teologiese Studies, 71(3), 1-9. 
Mansfield, L. (2008). Reconsidering feminism and the work of Norbert Elias for understanding gender, sport and sport-related activities. European Physical Education Review, 14, 93. United Kingdom: Sage.

Meho, L.I. \& Tibbo, H.R. (2003). Modelling the information-seeking behaviour of social scientists: Ellis's model revisited. Journal of the American Society of Information Science and Technology, 54(6), 570-587

Mennell, S. (1989). Norbert Elias: An introduction. Oxford: Basil Blackwell.

Mertens, D. M. (2014). Research and evaluation in education and psychology: Integrating diversity with quantitative, qualitative and mixed methods (4th ed.). Thousand Oaks, CA: Sage.

Modise, L.J. (2016). Liberation Theology as Doing Theology in Post-apartheid South Africa: Theoretical and Practical Perspectives. In Chimhanda, F.H., V.S. Molovi \& I.D. Mothoagae (ed.): African Theological Reflections: Critical Voices on Liberation, Leadership, Gender and Ecojustice. Theological Reflections on Sex as a Cleansing Ritual for African Widows 215 Pretoria: Unisa Press.

Neumann, W.L. (2011). Social research methods: quantitative and qualitative approaches. 7th edition. Boston: Allyn \& Bacon.

Nnodim A.U., Nwachukwu I. \& Ekumankama, O.O. (2015). The Effectiveness of Widow Support Systems in the Rural Areas of Rivers State, Nigeria

Nyangweso, M. (2017). Religion, Human Rights, and the African Widow. Peace Human Rights Governance, 1(3), 365-391.

Ocholla, D. \& Le Roux, J. (2011). Conceptions and Misconceptions of Theoretical Frameworks in Library and Information Science Research: A Case Study of Selected Theses and Dissertations from Eastern and Southern Universities. Mousaion, 29(2), 61-74.

Oniye O. A. (2007). Adjustment Strategies of Nigerian Widowhood Stress. Issue for Rehabilitation Counselling. African Journal of Educational Studies 1(2). From <http://www.sistscience.dev.net/img/bibliography> (Retrieved September 15, 2010).

Ravitch, S.M. \& Carl, N.M. (2016). Qualitative Research: Bridging the Conceptual; Theoretical, and Methodological. Thousand Oaks, CA: Sage.

Reid, K., Flowers, P. \& Larkin, M. (2005). Exploring lived Experience, The Psychologist, 18(1).

Saluun, P.M., Timin, L.A, Sokpo R.M. \& Shittu, S.T. (2019). The challenges of widowhood in the Nigeria contemporary society: the role of the church, International Journal of Arts and Humanities, 04, (02). ISSN: 2581-3102.

Sekgobela, G.L., Peu, D.M. \& van de Wath, A.E. (2018). Health Support needs of widows in South Africa: A phenomenological Inquiry. Journal of death and dying.

Shneiderman, S.B. \& Plaisant, C. (2005). Designing the user interface. 4th edition. ed: Pearson Addison Wesley, USA. 
Smith, D. (2001). Organizations and humiliation: Looking beyond Elias. Organization, 8(3), 537560. Sage Publications.

Smith, J.A. \& Osborn, M. (2007). 'Pain as an Assault on the Self: An Interpretative Phenomenological Analysis of the Psychological Impact of Chronic Back Pain.' Psychology and Health 22: 517-534.

Stones, C. (1988). 'Research: Towards a Phenomenological Praxis.' In D. Kruger (ed) An Introduction to Phenomenological Psychology (2 ed). Cape Town: Juta.

The Holy Bible. New International Version. NIV® Copyright @ 1973, 1978, 1984, 2011. Biblica®.

Wedekind, V. (2010). Further Education and Training Reform in South Africa: implications for college lecturers. Paper presented at the SAQA Research Seminar Series, 19 May, Pretoria.

Note: This study forms part of the research project: Investigating local indigenous community perspectives in response to the COVID-19 pandemic: An invisible enemy in the midst of our local households, supported by the National Institute for Humanities and Social Sciences (NIHSS), under Health and indigenous knowledge systems (IKS) Research Cluster. 